\title{
Growth performance, nitrogen balance, and metabolism of calcium and phosphorus in growing pigs fed diets supplemented with alpha-ketoglutarate
}

\author{
${ }^{4}$ Q1 J.S. Chen ${ }^{\mathrm{a}, \mathrm{c}, 1}$, F. Wu $^{\mathrm{b}, 1}$, H.S. Yang ${ }^{\mathrm{d}}$, F.N. Li ${ }^{\mathrm{b}}$, Q. Jiang ${ }^{\mathrm{b}}$, S.J. Liu ${ }^{\mathrm{b}}$, B.J. Kang ${ }^{\mathrm{a}}$, S. Li $^{\mathrm{a}}$,

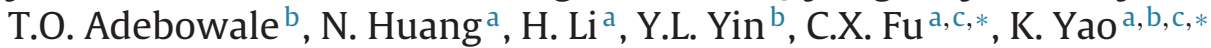 \\ a College of Animal Science and Technology, Hunan Agricultural University, Changsha, Hunan 410128, China \\ b Key Laboratory of Agro-ecological Processes in Subtropical Region, Hunan Provincial Engineering Research Center of Healthy Livestock, \\ Scientific Observing and Experimental Station of Animal Nutrition and Feed Science in South-Central, Ministry of Agriculture, Institute of \\ Subtropical Agriculture, Chinese Academy of Sciences, Changsha, Hunan 410125, China \\ ${ }^{c}$ Hunan Co-Innovation Center of Animal Production Safety, CICAPS, Changsha, Hunan 410128, China \\ d Animal Nutrition and Human Health Laboratory, School of Life Sciences, Hunan Normal University, Changsha, Hunan 410081, China
}

\section{A R T I C L E I N F O}

\section{Article history:}

Received 12 October 2016

Received in revised form

22 December 2016

Accepted 23 December 2016

Available online xxx

\section{Keywords:}

Alpha-ketoglutarate

Nitrogen balance

Calcium

Phosphorus

Pig

\begin{abstract}
A B S T R A C T
We investigated the effects of dietary alpha-ketoglutarate (AKG) supplementation on growth performance, the nitrogen $(\mathrm{N})$ balance, and metabolism of calcium $(\mathrm{Ca})$ and phosphorus $(P)$ in growing pigs. Sixteen healthy animals (Large $\times$ White $\times$ Landrace) of similar initial weight $(40.08 \pm 0.78 \mathrm{~kg})$ were randomly assigned to two dietary groups. The pigs were fed a basic diet containing either 0 (control) or $10 \mathrm{~g} \mathrm{AKG} \mathrm{kg}^{-1}$ for $28 \mathrm{~d}$. Their faeces and urine were collected continuously from Days 23-25. On Day 28, all of them were killed and their right rear femurs and tibias were removed. Pigs fed diets with AKG tended to have higher average daily gain (ADG; $P=0.088$ ), but their urinary-N levels and excretion of total $\mathrm{N}$ were $24.50 \%(P=0.012)$ and $23.67 \%(P=0.011)$ lower, respectively, when compared with corresponding values measured from the control group. However, their apparent $\mathrm{N}$-digestibility and net protein utilization were increased by $2.43 \%(P=0.044)$ and $11.84 \%(P=0.002)$, respectively, over the control. Furthermore, supplemental AKG decreased faecal- and urinary-Ca levels by $29.56 \%(P=0.045)$ and $24.54 \%(P=0.001)$, respectively, while enhancing P-retention, apparent Ca-digestibility, and apparent P-digestibility by $27.10 \%(P=0.002), 14.51 \%(P=0.041)$, and $16.62 \%(P=0.010)$, respectively. The addition of AKG also elevated the concentrations of ash, $P$, and $\mathrm{Ca}(P=0.012, P=0.002$, and $P=0.004$, respectively) in the femur samples, and increased bone density $(P=0.003)$, but did not affect those parameters in the tibias. These results indicate that dietary supplementation with AKG can improve the utilization of $\mathrm{N}, \mathrm{Ca}$, and $\mathrm{P}$; while effectively reducing $\mathrm{N}, \mathrm{Ca}$, and $\mathrm{P}$ emissions; and promoting $\mathrm{N}-, \mathrm{Ca}-$, and $\mathrm{P}-\mathrm{metabolism}$ in growing pigs.
\end{abstract}

(c) 2016 Elsevier B.V. All rights reserved.

\footnotetext{
Abbreviations: AKG, alpha-ketoglutarate; $\mathrm{NH}_{3}$, ammonia; $\mathrm{AA}$, amino acids; Glu, glutamate; Gln, glutamine; ADG, average daily gain; ADFI, average daily feed intake; F/G, feed intake/gain; DM, dry matter.

Q2 * Corresponding authors at: College of Animal Science and Technology, Hunan Agricultural University, Changsha, Hunan 410128, China

E-mail addresses: chenxing1110@gmail.com (C.X. Fu), yaokang@isa.ac.cn (K. Yao).

1 These authors contributed equally to this work.
}

Please cite this article in press as: Chen, J.S., et al., Growth performance, nitrogen balance, and metabolism of calcium and phosphorus in growing pigs fed diets supplemented with alpha-ketoglutarate. Anim. Feed Sci. Tech. (2017), http://dx.doi.org/10.1016/j.anifeedsci.2016.12.013 


\section{Introduction}

Concerns are rising in many countries about the excretion of minerals from pigs into the environment, as well as issues such as manure-handling and the emission of ammonia $\left(\mathrm{NH}_{3}\right)$ and odorous compounds from production sites (Norgaard et al., 2010). Volatilization of $\mathrm{NH}_{3}$ and high concentrations of phosphorus (P) in manure can cause eutrophication of natural ecosystems and affect local environmental conditions (Jongbloed and Lenis, 1992). Therefore, new approaches are needed for minimizing the excretion of pollutants from pig production systems. Dietary interventions can help improve the apparent absorption of calcium (Ca) and P (Jongbloed et al., 2000; Sauer et al., 2009; Madrid et al., 2013), and also reduce total- and urinary-nitrogen (N) excretions and $\mathrm{NH}_{3}$ emissions (Canh et al., 1998; Wang et al., 2009; Norgaard et al., 2010; Murphy et al., 2011).

Alpha-ketoglutarate (AKG) is a molecule that determines the overall rate of the citric acid cycle in an organism. Acting as a nitrogen scavenger, AKG leads to the formation of amino acids (AA) such as glutamate (Glu) and glutamine (Gln). The latter stimulates protein synthesis and inhibits protein degradation in muscles (Wu and Thompson, 1990; Zhou and Thompson, 1997). Because AKG has good water solubility, is non-toxic and relatively stable in water solutions, and can be rapidly transaminated (by glutamate dehydrogenase) to Glu, it appears to be the best alternative to Gln derivatives (Filip and Pierzynowski, 2007). In a study of growing rats, Jeevanandam et al. (1991) found that diets supplemented with AKG significantly reduced N-losses. This was also demonstrated by Prandini et al. (2012), who tested rats given AKG supplements of either 3 or $6 \mathrm{~g} \mathrm{~kg}^{-1}$ feed. In Atlantic salmon (Salmo salar), dietary supplementation with 5\% AKG reduced N-excretions without a negative effect on vitellogenin synthesis (Olin et al., 1992). Investigations by Blomqvist and Hammarqvist (1995) revealed that this molecule can prevent uncontrolled N-losses from muscle protein in human patients suffering from postsurgical trauma, burns, or chronic malnutrition, while Riedel et al. (1996) showed that AKG controls AA blood profiles and reduces the level of blood urea in patients undergoing hemodialysis. In vitro, AKG can spare Gln and activate the mTOR signaling pathway to stimulate protein synthesis in intestinal epithelial cells (Yao et al., 2012). In addition, Glu released from nerve fibers in bone tissue is synthesized by the reductive amination of its ketoacid ( $\alpha$-ketoglutaric acid) that occurs in peri-vein hepatocytes (Stoll et al., 1991). This then gives rise to an increase in proline synthesis, which plays a key role in the production of collagen (Kristensen et al., 2002). Dietary AKG supplementation also increases bone mineral density and homeostasis in turkeys (Meleagris gallopavo) (Tatara et al., 2004a, 2005) and pigs (Sus scrofa) (Kowalik et al., 2005; Tatara et al., 2012), and can improve the mechanical properties of ribs in ram lambs (Ovis aries) (Tatara et al., 2007). Based on all of these reported benefits, we hypothesized here that AKG supplementation would have a positive influence on growth performance, the $\mathrm{N}$ balance, and $\mathrm{Ca}$ and $\mathrm{P}$ metabolism in pigs.

\section{Materials and methods}

All procedures were approved by the Committee of Animal Care at the Institute of Subtropical Agriculture, Chinese Academy of Sciences. The AKG (purity $\geq 98 \%$ ) component was obtained from Hubei Yuancheng Saichuang Technology Co., Ltd., Wuhan 430064, China.

\subsection{Animals and diets}

Sixteen healthy growing pigs (Large $\times$ White $\times$ Landrace; $84 \pm 1 \mathrm{~d}$ ) of similar initial weight $-40.08 \pm 0.78 \mathrm{~kg}-$ were randomly assigned to two different experimental diets: (1) control group $(n=8)$, which was given feed that contained the main components of corn and soybean meal, as optimized according to the National Research Council (NRC, 2012) to meet nutrient requirements (basic diet); or (2) supplemented diet ( $\mathrm{n}=8$ ), in which $10 \mathrm{~g} \mathrm{~kg}^{-1}$ of AKG was added to the basic diet components, and 1.0\% corn in the basal diet was replaced by 1.0\% AKG. All diets were isocaloric (Table 1).

\subsection{Feeding and sample collection}

Each animal was housed in a stainless steel metabolic cage $(150 \mathrm{~cm}$ long $\times 105 \mathrm{~cm}$ wide $\times 120 \mathrm{~cm}$ high). All pigs were located in the same air-conditioned room, fed at 0800 and $1700 \mathrm{~h}$, and given free access to water throughout the experiment. They were adapted to the experimental diets and their cages for $7 \mathrm{~d}$ before the 28- $\mathrm{d}$ trial period began.

The N-balance evaluations ran concurrently with the assessment of performance, and the pigs were offered the same diets for each part of the study. Individual body weights and feed consumption per cage were measured on Day 28 to calculate the average daily gain (ADG), average daily feed intake (ADFI), and feed-to-gain ratio (F/G). Urine and feces were collected separately from each pig and weighed twice daily for $3 \mathrm{~d}$ (from day 23-25). Fecal output was collected daily before the animals were fed. To avoid any loss of ammonia-N, we added $5 \mathrm{~g}$ of fresh manure to $10 \mathrm{~mL}$ of $10 \%$ sulfuric acid and mixed it thoroughly. Urine samples were collected in plastic containers, weighed, and recorded. Afterward, $20 \%$ of those samples were kept to evaluate $\mathrm{N}$-retention. Evaporation of $\mathrm{NH}_{3}$ was prevented by adding $10 \mathrm{~mL}$ of sulfuric acid per $100 \mathrm{~mL}$ of urine to each collection bottle. All samples were stored at $-80^{\circ} \mathrm{C}$. 
Table 1

Ingredient and chemical composition of the experimental diets (as fed basis).

\begin{tabular}{|c|c|c|}
\hline Item & Control & $+\mathrm{AKG}$ \\
\hline \multicolumn{3}{|l|}{ Ingredients, $\mathrm{g} / \mathrm{kg}$} \\
\hline Soybean meal & 234.0 & 234.0 \\
\hline Corn & 691.7 & 681.7 \\
\hline $\mathrm{AKG}^{\mathrm{a}}$ & & 10.0 \\
\hline Soybean oil & 28.3 & 28.3 \\
\hline Limestone & 8.7 & 8.7 \\
\hline Monocalcium phosphate & 11.0 & 11.0 \\
\hline L-Lysine- $\mathrm{HCl}$ & 4.1 & 4.1 \\
\hline L-Threonine & 1.1 & 1.1 \\
\hline DL-Methionine & 0.9 & 0.9 \\
\hline L-Tryptophan & 0.2 & 0.2 \\
\hline Sodium chloride & 4.0 & 4.0 \\
\hline Sodium bicarbonate & 6.0 & 6.0 \\
\hline Premix $^{b}$ & 10.0 & 10.0 \\
\hline \multicolumn{3}{|l|}{ Chemical analysis, $\mathrm{g} / \mathrm{kg}$} \\
\hline Metabolizable energy ${ }^{\mathrm{c}}, \mathrm{kcal} \mathrm{kg}^{-1}$ & 3270.4 & 3270.4 \\
\hline Crude protein & 159.9 & 158.5 \\
\hline Lysine & 10.8 & 10.7 \\
\hline Methionine & 3.1 & 3.1 \\
\hline Methionine + cysteine & 5.4 & 5.3 \\
\hline Threonine & 5.9 & 5.8 \\
\hline Tryptophan & 1.7 & 1.7 \\
\hline Calcium & 6.6 & 6.6 \\
\hline Total phosphorus & 5.1 & 5.1 \\
\hline
\end{tabular}

a $\mathrm{AKG}=$ alpha-ketoglutarate.

b Provided per kg of diet (as-fed basis): vitamin A: 15,000 IU; vitamin $\mathrm{D}_{3}$ : $2000 \mathrm{IU}$; vitamin E: $30 \mathrm{mg}$; vitamin K: $1 \mathrm{mg}$; vitamin $\mathrm{B}_{1}: 1 \mathrm{mg}$; vitamin $\mathrm{B}_{2}$ : $1.5 \mathrm{mg}$; vitamin $\mathrm{B}_{6}: 2 \mathrm{mg}$; vitamin $\mathrm{B}_{12}: 0.02 \mathrm{mg}$; nicotinic acid: $12 \mathrm{mg}$; pantothenic acid: $10.5 \mathrm{mg}$; biotin: $0.05 \mathrm{mg}$; folic acid: $0.3 \mathrm{mg}$; choline chloride $600 \mathrm{mg} / \mathrm{kg}$ : antioxidant: $800 \mathrm{mg}$; Cu: $5.6 \mathrm{mg}$; Mn:6.5 mg; Fe: $52 \mathrm{mg}$; Zn: $51 \mathrm{mg}$; I: $1 \mathrm{mg}$; Se: $0.15 \mathrm{mg}$.

c Calculated value.

\subsection{Analyses of diets, faeces, and urine}

At the end of the trials, all samples were analyzed in duplicate. The dry matter (DM) contents of diets and faeces were determined by oven-drying at $105^{\circ} \mathrm{C}$ for $8 \mathrm{~h}$ and at $65^{\circ} \mathrm{C}$, respectively, to achieve a constant weight. The dried samples were then ground to pass through a 1-mm sieve. Nitrogen levels in those diet, urine, or fecal samples were determined by a modified Kjeldahl method (AOAC, 2006). For mineral analysis, samples of diets and faeces were ashed at $550{ }^{\circ} \mathrm{C}$ for $8 \mathrm{~h}$ in a muffle furnace. The urine samples were oven-dried at $80^{\circ} \mathrm{C}$ for $24 \mathrm{~h}$ and then ashed at $550^{\circ} \mathrm{C}$ for $8 \mathrm{~h}$ in a muffle furnace. All ash samples were diluted in $0.6 \mathrm{~N} \mathrm{HNO}_{3}$ solutions and filtered to analyze Ca and P concentrations with an inductively coupled plasma optical emission spectrometer (ICP-OES)(Perkin Elmer 8000; Waltham, MA,109 USA) in the emission line of 317.93 and $214.91 \mathrm{~nm}$, respectively(Dorea and Myazaki, 1998).

\subsection{Bone analysis}

The right rear foot of each pig was manually cleaned of all skin, muscle, and connective tissue before removing the femur and tibia. Bones were analyzed for ash, Ca, and P concentrations as described by Madrid et al. (2013). Their density was measured with a quantitative ultrasound instrument (SONOST-3000; OsteoSys, Guro-Ku, Korea).To determine their fat-free dry matter, we autoclaved the bones at $121^{\circ} \mathrm{C}$ for $30 \mathrm{~min}$, then de-fatted the samples with ethyl ether for $72 \mathrm{~h}$. They were then dried again at $110^{\circ} \mathrm{C}$ for $24 \mathrm{~h}$, re-weighed, and finally ashed at $550^{\circ} \mathrm{C}$ in a muffle furnace for $36 \mathrm{~h}$. Each ash sample was diluted in $0.6 \mathrm{~N} \mathrm{HNO}_{3}$ and filtered. The Ca and $\mathrm{P}$ concentrations were determined with the ICP-OES.

\subsection{Statistical analysis}

All values were presented as means \pm standard error ( \pm S.E.). For all parameters, the data were analyzed statistically by one-way ANOVA, using SPSS v. 20.0 (SPSS Inc., Chicago, IL, USA). The individual pig was considered as the experimental unit. Differences were considered statistically significant at $P<0.05$ and trends were considered at $0.05<P<0.10$.

\section{Results}

\subsection{Growth performance}

No health problems arose during the digestion and metabolism experiments, and no feed refusals were observed. The initial BW values did not differ between diet groups (Table 2). Throughout the entire trial period, pigs receiving the AKG 
Table 2

Effects of dietary supplementation with AKG on growth performance of pigs. ${ }^{\text {a,b }}$

\begin{tabular}{|c|c|c|c|c|}
\hline \multirow[t]{2}{*}{ Item } & \multicolumn{2}{|c|}{$\mathrm{AKG}\left(\mathrm{g} \mathrm{kg}^{-1}\right)$} & \multirow[t]{2}{*}{ SEM $^{\mathrm{c}}$} & \multirow[t]{2}{*}{$P$-value } \\
\hline & 0 & 10 & & \\
\hline Initial body weight (kg) & 40.0 & 40.2 & 0.465 & 0.923 \\
\hline Final body weight (kg) & 63.9 & 65.3 & 0.359 & 0.347 \\
\hline $\operatorname{ADF}\left(\mathrm{g} \mathrm{d}^{-1}\right)$ & 855 & 898 & 5.38 & 0.088 \\
\hline $\operatorname{ADFI}\left(\mathrm{g} \mathrm{d}^{-1}\right)$ & 2146.3 & 2210.7 & 37.5 & 0.682 \\
\hline $\mathrm{F} / \mathrm{G}$ & 2.52 & 2.45 & 0.046 & 0.761 \\
\hline
\end{tabular}

a ADG, average daily gain; ADFI, average daily feed intake; $F / G$, feed intake/gain.

b Pigs ( $84 \pm 1$ days of age) fed experimental treatments from day 0-28 (40-65 kg body weight).

c SEM, pooled standard error of means $(n=8)$.

Table 3

Effects of dietary supplementation with AKG on $\mathrm{N}$ balance in pigs. ${ }^{\mathrm{a}}$

\begin{tabular}{|c|c|c|c|c|}
\hline \multirow[t]{2}{*}{ Item } & \multicolumn{2}{|c|}{$\mathrm{AKG}\left(\mathrm{g} \mathrm{kg}^{-1}\right)$} & \multirow[t]{2}{*}{$\mathrm{SEM}^{\mathrm{b}}$} & \multirow[t]{2}{*}{$P$-value } \\
\hline & 0 & 10 & & \\
\hline Dry matter intake $\left(\mathrm{kg} \mathrm{d}^{-1}\right)$ & 2.35 & 2.44 & 0.027 & 0.496 \\
\hline $\mathrm{N}$-intake $\left(\mathrm{g} \mathrm{d}^{-1}\right)$ & 62.8 & 64.1 & 0.722 & 0.667 \\
\hline Faecal-N $\left(\mathrm{g} \mathrm{d}^{-1}\right)$ & 6.08 & 4.77 & 0.175 & 0.099 \\
\hline Urinary-N $\left(\mathrm{g} \mathrm{d}^{-1}\right)$ & 14.5 & 11.0 & 0.276 & 0.012 \\
\hline Total-N excretion $\left(\mathrm{g} \mathrm{d}^{-1}\right)$ & 20.6 & 15.7 & 0.379 & 0.011 \\
\hline $\mathrm{N}$-retention $\left(\mathrm{g} \mathrm{d}^{-1}\right)$ & 42.2 & 48.3 & 0.570 & 0.072 \\
\hline Apparent N-digestibility (\%) & 90.4 & 92.6 & 0.228 & 0.044 \\
\hline Net protein utilization (\%) & 70.4 & 78.8 & 0.476 & 0.002 \\
\hline Total N emission rate (\%) & 32.8 & 24.5 & 0.470 & 0.002 \\
\hline
\end{tabular}

a Pigs fed experimental treatments and samples collected twice daily from all pigs on days 23-25.

b SEM, pooled standard error of means $(n=8)$.

Table 4

Effects of dietary supplementation with AKG on calcium and phosphorus metabolism in pigs. ${ }^{\mathrm{a}}$

\begin{tabular}{|c|c|c|c|c|}
\hline \multirow[t]{2}{*}{ Item } & \multicolumn{2}{|c|}{$\mathrm{AKG}\left(\mathrm{g} \mathrm{kg}^{-1}\right)$} & \multirow[t]{2}{*}{ SEM $^{\mathrm{b}}$} & \multirow[t]{2}{*}{$P$-value } \\
\hline & 0 & 10 & & \\
\hline P-intake $\left(\mathrm{g} \mathrm{d}^{-1}\right)$ & 13.3 & 14.3 & 0.155 & 0.142 \\
\hline Faecal-P $\left(\mathrm{g} \mathrm{d}^{-1}\right)$ & 4.54 & 3.31 & 0.136 & 0.052 \\
\hline Urinary-P $\left(\mathrm{g} \mathrm{d}^{-1}\right)$ & 0.18 & 0.13 & 0.008 & 0.144 \\
\hline P-retention $\left(\mathrm{g} \mathrm{d}^{-1}\right)$ & 8.56 & 10.9 & 0.128 & 0.002 \\
\hline Apparent P-digestibility (\%) & 66.0 & 77.0 & 0.814 & 0.010 \\
\hline Ca-intake $\left(\mathrm{g} \mathrm{d}^{-1}\right)$ & 19.0 & 18.4 & 0.211 & 0.545 \\
\hline Faecal-Ca $\left(\mathrm{g} \mathrm{d}^{-1}\right)$ & 6.63 & 4.67 & 0.205 & 0.045 \\
\hline Urinary-Ca $\left(\mathrm{g} \mathrm{d}^{-1}\right)$ & 1.63 & 1.23 & 0.018 & 0.001 \\
\hline Ca-retention $\left(\mathrm{g} \mathrm{d}^{-1}\right)$ & 10.7 & 12.5 & 0.207 & 0.060 \\
\hline Apparent Ca-digestibility (\%) & 65.2 & 74.7 & 0.971 & 0.041 \\
\hline
\end{tabular}

a Pigs fed experimental treatments and samples collected twice daily from all pigs on days 23-25.

b SEM, pooled standard error of means $(n=8)$.

diet tended to increase in ADG $(P=0.088)$. However, this supplement had no effect on ADFI and $\mathrm{F} / \mathrm{G}(P=0.682$ and $P=0.761$, respectively) when compared with the control (basic diet) group.

\subsection{Nitrogen balance}

The intake of $\mathrm{N}$ did not differ significantly between diet groups $(P=0.667)$ (Table 3$)$. Faecal- $\mathrm{N}(P=0.099)$ tended to decrease while N-retention $(P=0.072)$ tended to increase for pigs fed with AKG when compared with the control group. However, excretion of total $\mathrm{N}(P=0.011)$ and urine- $\mathrm{N}(P=0.012)$, and the total $\mathrm{N}$ emission rate $(P=0.002)$ were lower for the AKG pigs. Therefore, apparent $\mathrm{N}$-digestibility $(P=0.044)$ and net protein utilization $(P=0.002)$ were higher than levels measured in the control group.

\subsection{Phosphorus and calcium metabolism}

The intake of $C a$ and $P(P=0.545$ and $P=0.142$, respectively $)$ and the level of $P$ in the urine $(P=0.144)$ were not affected by the AKG supplement (Table 4). Faecal-P $(P=0.052)$ tended to decrease while Ca-retention $(P=0.060)$ increased for pigs fed with AKG. However, when compared with the control group, P-retention was significantly higher $(P=0.002)$ and the daily 
Table 5

Effect of dietary supplementation with AKG on bone parameters in pigs. ${ }^{\text {a }}$

\begin{tabular}{|c|c|c|c|c|}
\hline \multirow[t]{2}{*}{ Item } & \multicolumn{2}{|c|}{$\mathrm{AKG}\left(\mathrm{g} \mathrm{kg}^{-1}\right)$} & \multirow[t]{2}{*}{ SEM $^{\mathrm{b}}$} & \multirow[t]{2}{*}{$P$-value } \\
\hline & 0 & 10 & & \\
\hline \multicolumn{5}{|l|}{ Femur } \\
\hline Ash $\left(\mathrm{g} \mathrm{kg}^{-1}\right)$ & 463 & 493 & 1.68 & 0.012 \\
\hline $\mathrm{P}\left(\mathrm{g} \mathrm{kg}^{-1}\right)$ & 75.9 & 89.3 & 0.484 & 0.002 \\
\hline $\mathrm{Ca}\left(\mathrm{g} \mathrm{kg}^{-1}\right)$ & 167 & 202 & 1.47 & 0.004 \\
\hline Bone density $\left(\mathrm{g} \mathrm{cm}^{-3}\right)$ & 2.35 & 2.46 & 0.004 & 0.003 \\
\hline \multicolumn{5}{|l|}{ Tibia } \\
\hline Ash $\left(\mathrm{g} \mathrm{kg}^{-1}\right)$ & 513 & 511 & 4.17 & 0.933 \\
\hline $\mathrm{P}\left(\mathrm{g} \mathrm{kg}^{-1}\right)$ & 94.4 & 92.5 & 1.21 & 0.866 \\
\hline $\mathrm{Ca}\left(\mathrm{g} \mathrm{kg}^{-1}\right)$ & 207 & 204 & 3.05 & 0.784 \\
\hline Bone density $\left(\mathrm{g} \mathrm{cm}^{-3}\right)$ & 2.52 & 2.48 & 0.011 & 0.641 \\
\hline
\end{tabular}

a At the end of the 28 days of bone parameters study.

b SEM, pooled standard error of means $(n=8)$.

amounts of Ca excreted via the faeces and urine $(P=0.045$ and $P=0.001$, respectively $)$ were significantly lower. As a result, the apparent digestibility of $\mathrm{P}(P=0.010)$ and $\mathrm{Ca}(P=0.041)$ was enhanced by the addition of AKG.

The inclusion of AKG in the diet increased the concentrations of ash, $\mathrm{P}$, and $\mathrm{Ca}(P=0.012, P=0.002$, and $P=0.004$, respectively) in the femurs from AKG-treated animals, as well as their bone density $(P=0.003)$ (Table 5). However, that supplement did not influence those values in their tibias.

\section{Discussion}

Previous study demonstrated that AKG has been added to the diets of pigs to improve ADG and feed-efficiency (Hou et al., 2011), femur mineral density (Kowalik et al., 2005), and skeletal properties (Tatara et al., 2012). We found here that dietary supplementation with AKG tended to improve average daily gains when compared with animals who received only the basic diet. Wang et al. (2015) have reported, with juvenile hybrid sturgeon (Acipenser schrenckii $\times$ A. baerii), that supplementing $10 \mathrm{~g} \mathrm{AKG} \mathrm{kg}^{-1}$ of feed improves their rate of weight gain and the ratio of protein-efficiency. These effects might be explained as follows. Development of the intestine is promoted by AKG supplementation, which then enhances growth performance. Liu et al. (2009) have found that this molecule reverses the depression in growth rates for weaned piglets challenged by lipopolysaccharide (LPS), and improves the intestinal morphology and function in healthy young pigs without LPS challenges. Hou et al. (2010) have demonstrated that supplementing the diet with $10 \mathrm{~g} \mathrm{AKG} \mathrm{kg}^{-1}$ of feed alleviates mucosal damage and stimulates the absorptive function of the small intestine in LPS-challenged piglets. Other studies have shown that supplementation with organic acids, such as fumaric, citric and formic acids, in pig diets can slightly increase the performance of grower-finisher pigs (Ravindran and Kornegay, 1993; Partanen and Mroz, 1999). This promoter effect of organic acids may be due to increased AA- and energy-digestibilities (Mroz et al., 1998; Blank et al., 1999), higher $\mathrm{N}$-retention (Kirchgessner and Roth, 2009), and a reduction in populations of harmful bacteria and their metabolites in the gastrointestinal tract.

The AKG molecule is a precursor not only of Gln and arginine, but also of keto acids such as alpha-ketoisocaproate, a precursor of hydroxy-methyl-butyrate, which protects protein catabolism (Pierzynowski and Sjodin, 1998). Thus, AKG has an important physiological role in protein synthesis (Blomqvist and Hammarqvist, 1995) and AA-metabolism (Riedel et al., 1996; Tatara et al., 2005). In research with growing rats, Jeevanandam et al. (1991) showed that diets supplemented with AKG helped significantly in reducing N-losses. Prandini et al. (2012) also found that, when added at rates of either 3 or $6 \mathrm{~g} \mathrm{~kg}^{-1}$ of feed, AKG decreased endogenous N-losses. In Atlantic salmon, dietary supplementation with 5\% AKG diminishes $\mathrm{N}$-excretions (Olin et al., 1992). Our data demonstrated that the dietary AKG supplementation reduced N-excretion in the urine, while also decreasing the content of total $\mathrm{N}$ and the rate of its emission. Furthermore, this additive increased apparent $\mathrm{N}$-digestibility and net protein utilization, thereby improving N-retention. This was reflected by the rise in average daily gains in those pigs over the entire experimental period. All of these findings suggest that AKG is an important source of Gln and Glu, which stimulates protein synthesis, inhibits protein degradation in muscle, provides a valuable metabolic fuel for cells in the gastrointestinal tract, and, consequently, promotes N-depositions in cells throughout the organism (Hammarqvist et al., 1991; Blomqvist and Hammarqvist, 1995; Jones et al., 1999; Yao et al., 2012). In addition, smaller N-losses due to AKG are beneficial to the growth and integrity of the intestines (Hou et al., 2011). The gastrointestinal tract actively participates in $\mathrm{N}$-recycling in the gut and plays an important role in animal nutrition and health (Bergen and $\mathrm{Wu}, 2009$ ).

We showed here that AKG increased the apparent digestibility of Ca and P, decreased excretions of Ca and P in the feces, and, consequently, improved the retention of Ca and P. However, it remains unclear why this molecule has such an effect on those processes (Sauer et al., 2009). Although researchers have not identified a relationship between the dose or type of acid and improvements in mineral digestibility, some experiments have indicated that supplementing pig diets with organic acids, e.g., benzoic, citric, lactic, formic, butyric, or fumaric acids, might improve the utilization of Ca and P (Höhler and Pallauf, 1993; Han et al., 1998; Kemme et al., 1999; Jongbloed et al., 2000; Sauer et al., 2009). This effect on digestibility may 
be due to enhanced solubility and absorption of minerals (Jongbloed, 1987), which can lower the pH of gastric contents and, indirectly, reduce the rate of gastric-emptying (Sauer et al., 2009). Such a positive influence can lead to the proliferation of epithelial cells in the gastrointestinal mucosa, which allows for more efficient mineral absorption (Sakata et al., 1995).

The conversion of pro-collagen to collagen and formation of the bone matrix can be increased by AKG, ascorbate, and $\mathrm{Fe}^{2+}$, which steer the hydroxylation of peptide-bound proline to hydroxyproline via prolyl hydrolase (Kristensen et al., 2002; Dąbek et al., 2006). Regardless of the mechanism, daily administration of AKG improves bone mineral density and can be beneficial to mechanical and geometrical properties (Harrison et al., 2004; Tatara et al., 2004b, 2005, 2012; Kowalik et al., 2005; Andersen et al., 2008). In pigs, $0.1 \mathrm{~g} \mathrm{~kg}^{-1}$ of AKG fed per day significantly increases femur cortical mineral density (Andersen et al., 2008). In another investigation $0.4 \mathrm{~g} \mathrm{~kg}^{-1}$ of body weight per day AKG was given to pigs from birth to the 70 th day of postnatal life, a significant increase in the femur cortical density of approximately $2 \%$ and $7 \%$ was observed after 56 and 70 days of AKG treatment respectively (Kowalik et al., 2005). Furthermore, Harrison et al. (2004) reported that $0.1 \mathrm{~g} \mathrm{~kg}^{-1}$ of body weight per day AKG administered orally to growing lambs postnatally, positively influences volumetric bone density in the femur. In the present study, our trials also showed that dietary supplementation increased femur bone density. This is to some extent similar to the previous study where few long-term effects of AKG are found in the weight bearing bones such as femur, being related to cortical bone density. Moreover, in turkeys, 14 weeks of AKG administration can enhance mineral density in their tibias by 5.5\% over levels measured in the untreated control group (Tatara et al., 2004a). However, we found no such effect on densities in the tibias of our pigs. It should be emphasized that these studies were performed during a period of intensive development of the skeletal system in pigs, as well as turkeys, when very rapid processes of bone modelling and remodelling take place. The modelling process is much more effective than remodelling for increasing bone mass (Rauch, 2007). It seemed to indicated that beneficial and long-term effects of nutritional intervention with AKG at an early stage of neonatal life on skeletal system development (Andersen et al., 2008). Thus, under the current experimental conditions, the authors speculated that all discrepancies reported in bone values may be attributed to feeding diets from birth, and species differences between pigs and turkeys account for this contrast in responsiveness to AKG. However, further studies will be needed to clearly address this hypothesis.

Our investigation indicated that AKG increases the concentrations of ash, $\mathrm{P}$, and $\mathrm{Ca}$ in pig femurs but did not influence those values in their tibias. Both Ca and P are essential for bone development and the support of soft tissues (Shapiro and Heaney, 2003). However, only a few studies have examined the relationship between AKG and bone concentrations of P and $\mathrm{Ca}$. Some researchers have shown that animal diets supplemented with benzoic acid, propionic acid, acetic acid, and L-lactic acid can help improve Ca and P contents (Ibardolaza et al., 1993; Chonan et al., 1998; Kishi et al., 1999; Sauer et al., 2009). Sauer et al. (2009) have reported that inclusion of benzoic acid linearly increases the concentrations of $P$ in femur and ash samples. In tests with broiler chickens (Gallus domesticus), the levels of ash and Ca in bones rise in response to the addition of 3\% propionic acid (Ibardolaza et al., 1993). These findings provide further evidence that dietary acids are conducive to better mineral nutrition. Concentrations of Ca are also elevated when 1.6\% acetic acid (Kishi et al., 1999) or 2.5\% L-lactic acid (Chonan et al., 1998) is added to the diet of rats. Indeed the data in the present study seem to support this hypothesis that there were some differences between femur and tibia in terms of $\mathrm{Ca}$ and P metabolism. However, the mechanism by which this is achieved requires further examination.

\section{Conclusions}

Dietary supplementation with AKG can affect the $\mathrm{N}$ balance and rate of $\mathrm{N}$-utilization. This molecule also helps regulate the pattern of N-excretion by decreasing the excretion of urinary-N and total-N. Furthermore, AKG enhances the utilization of $\mathrm{Ca}$ and $\mathrm{P}$, effectively reducing their excretion while promoting their metabolism. We found that bone concentrations of $\mathrm{Ca}$ and $\mathrm{P}$ were lower and that femur density was improved by AKG supplementation. Therefore, alpha-ketoglutarate has a positive influence on the utilization and metabolism of $\mathrm{N}, \mathrm{Ca}$, and $\mathrm{P}$ in growing pigs.

\section{Acknowledgements}

This work was supported by the National Basic Research Program of China (2013CB127306), the National Natural Science Foundation of China (31472107), the Chinese Academy of Sciences 'Hundred Talent' award, the National Science Foundation for Distinguished Young Scholars of Hunan Province (2016JJ1015) and the Open Foundation of Key Laboratory of Agroecological Processes in Subtropical Region, Institute of Subtropical Agriculture, Chinese Academy of Sciences (ISA2016101).

\section{References}

AOAC, 2006. Official Methods of Analysis of AOAC International, No. 984.13. Association of Official Analytical Chemists International, Gaithersburg, MD, USA.

Andersen, N.K., Tatara, M.R., Krupski, W., Majcher, P., Harrison, A.P., 2008. The long-term effect of $\alpha$-ketoglutarate, given early in postnatal life, on both growth and various bone parameters in pigs. J. Anim. Physiol. Anim. Nutr. 92, 519-528. 
Bergen, W., Wu, G., 2009. Intestinal nitrogen recycling and utilization in health and disease. J. Nutr. 139, 821-825.

Blank, R., Mosenthin, R., Sauer, W.C., Huang, S., 1999. Effect of fumaric acid and dietary buffering capacity on ileal and fecal amino acid digestibilities in early-weaned pigs. J. Anim. Sci. 77, 2974-2984.

Blomqvist, B.I., Hammarqvist, F., 1995. Glutamine and alpha-ketoglutarate prevent the decrease in muscle free glutamine concentration and influence protein synthesis after total hip replacement. Metabolism 44, 1215-1222.

Canh, T.T., Schrama, J.W., Aja, A., Mwa, V., Cevan, K., Mjw, H., 1998. Effect of dietary fermentable fibre from pressed sugar-beet pulp silage on ammonia emission from slurry of growing-finishing pigs. Anim. Sci. 67, 583-590.

Chonan, O., Takahashi, R., Yasui, H., Watanuki, M., 1998. Effect of L-lactic acid on the absorption of calcium in gastrectomized rats. J. Nutr. Sci. Vitaminol. 44, 869-875.

Dạbek, M., Kruszewska, D., Filip, R., Hotowy, A., Pierzynowski, Ł., Wojtasz-Pająk, A., Szymanczyk, S., Piedra, J.L.V., Werpachowska, E., Pierzynowski, S.G., 2006. $\alpha$-Ketoglutarate (AKG) absorption from pig intestine and plasma pharmacokinetics. J. Anim. Physiol. Anim. Nutr. 89, 419-426.

Dorea, J.G., Myazaki, E., 1998. Calcium and phosphorus in milk of Brazilian mothers using oral contraceptives. J. Am. Coll. Nutr. 17, 642-646.

Filip, R., Pierzynowski, S.G., 2007. The role of glutamine and a-ketoglutarate in gut metabolism and the potential application in medicine and nutrition. J. Clin. Res. 1, 9-15.

Höhler, D.D., Pallauf, P.D.J., 1993. Untersuchungen zum einfluß von citronensäure auf die mineralstoffverwertung beim ferkel anhand einer mais-soja-diät mit und ohne Zn-ergänzung. J. Anim. Physiol. Anim. Nutr. 69, 133-142.

Hammarqvist, F., Wernerman, J., von der Decken, A., Vinnars, E., 1991. Alpha-ketoglutarate preserves protein synthesis and free glutamine in skeletal muscle after surgery. Surgery 109, 28-36.

Han, Y.M., Roneker, K.R., Pond, W.G., Lei, X.G., 1998. Adding wheat middlings, microbial phytase, and citric acid to corn-soybean meal diets for growing pigs may replace inorganic phosphorus supplementation. J. Anim. Sci. 76, 2649-2656.

Harrison, A.P., Tygesen, M.P., Sawa-Wojtanowicz, B., Husted, S., Tatara, M.R., 2004. Alpha-ketoglutarate treatment early in postnatal life improves bone density in lambs at slaughter. Bone 35, 204-209.

Hou, Y.Q., Wang, L., Ding, B.Y., Liu, Y.L., Zhu, H.L., Liu, J., Li, Y.T., Wu, X., Yin, Y.L., Wu, G.Y., 2010. Dietary $\alpha$-ketoglutarate supplementation ameliorates intestinal injury in lipopolysaccharide-challenged piglets. Amino Acids 39, 555-564.

Hou, Y.Q., Wang, L., Ding, B.Y., Liu, Y.L., Zhu, H.L., Liu, J., Li, Y.T., Kang, P., Yin, Y.L., Wu, G.Y., 2011. Alpha-ketoglutarate and intestinal function. Front. Biosci. $16,1186-1196$.

Ibardolaza, E.I., Isshiki, Y., Yamauchi, K.E., Nakahiro, Y., 1993. Effects of dietary propionic acid on breaking strength and calcium content of the tarsometatarsal bone in broiler chickens. J. Poult. Sci. 30, 175-182.

Jeevanandam, M., Ali, M.R., Ramias, L., Schiller, W.R., 1991. Efficacy of ornithine-alpha-ketoglutarate (OKGA) as a dietary supplement in growing rats. Clin. Nutr. 10, 155-161.

Jones, C., Palmer, T.E.A., Griffiths, R., 1999. Randomized clinical outcome study of critically ill patients given glutamine-supplemented enteral nutrition. Nutrition 15, 108-115.

Jongbloed, A.W., Lenis, N.P., 1992. Alteration of nutrition as a means to reduce environmental pollution by pigs. Livest. Prod. Sci. 31, 75-94.

Jongbloed, A.W., Mroz, Z., Weij-Jongbloed, R.V.D., Kemme, P.A., 2000. The effects of microbial phytase, organic acids and their interaction in diets for growing pigs. Livest. Prod. Sci. 67, 113-122.

Jongbloed, A.W., 1987. Phosphorus in the feeding of pigs. In: Effect of the Diet on the Absorption and Retention of Phosphorous by Growing Pigs. PhD Thesis. Wageningen University, The Netherlands.

Kemme, P.A., Jongbloed, A.W., Mroz, Z., Kogut, J., Beynen, A.C., 1999. Digestibility of nutrients in growing-finishing pigs is affected by Aspergillus niger phytase, phytate and lactic acid levels: 1 . Apparent ileal digestibility of amino acids. Livest. Prod. Sci. 58, 107-117.

Kirchgessner, M., Roth, F.X., 2009. Verdaulichkeit und bilanz von protein, energie und einigen mineralstoffen bei fumarsäurezulagen an ferkel. J. Anim. Physiol. Anim. Nutr. 44, 239-246.

Kishi, M., Fukaya, M., Tsukamoto, Y., Nagasawa, T., Takehana, K., Nishizawa, N., 1999. Enhancing effect of dietary vinegar on the intestinal absorption of calcium in ovariectomized rats. Biosci. Biotechnol. Biochem. 63, 905-910.

Kowalik, S., Sliwa, E., Tatara, M.R., Krupski, W., Majcher, P., Studzinski, T., 2005. Influence of alpha-ketoglutarate on mineral density and geometrical and mechanical parameters of femora during postnatal life in piglets. Bull. Vet. Inst. Pulawy 49, 107-111.

Kristensen, N.B., Jungvid, H., Fernández, J.A., Pierzynowski, S.G., 2002. Absorption and metabolism of $\alpha$-ketoglutarate in growing pigs. J. Anim. Physiol. Anim. Nutr. 86, 239-245.

Liu, J., Hou, Y.Q., Ding, B.Y., Liu, Y.L., Zhu, H.L., Wang, L., Li, Y.T., 2009. Attenuating effect of $\alpha$-ketoglutaric acid on growth depression in weaned pigs challenged with lipopolysaccharide. Chin. J. Anim. Nutr. 21, 519-524.

Madrid, J., Martínez, S., López, C., Hernández, F., 2013. Effect of phytase on nutrient digestibility, mineral utilization and performance in growing pigs. Livest. Sci. 154, 144-151.

Mroz, Z., Jongbloed, A.W., Partanen, K., Diepen, J.T.M., Vreman, K., Kogut, J., 1998. Ileal digestibility of amino acids in pigs fed diets of different buffering capacity and with supplementary organic acids. J. Anim. Feed. Sci. 7 (2), 191-197.

Murphy, D.P., O'Doherty, J.V., Boland, T.M., O'Shea, C.J., Callan, J.J., Pierce, K.M., Lynch, M.B., 2011. The effect of benzoic acid concentration on nitrogen metabolism, manure ammonia and odour emissions in finishing pigs. Anim. Feed Sci. Technol. 163, 194-199.

NRC, 2012. Nutrient Requirements of Swine, 11th rev. ed. Natl. Acad. Press, Washigton, DC.

Norgaard, J.V., Fernandez, J.A., Eriksen, J., Olsen, O.H., Carlson, D., Poulsen, H.D., 2010. Urine acidification and mineral metabolism in growing pigs fed diets supplemented with dietary methionine and benzoic acid. Livest. Sci. 134, 113-115.

Olin, T., Bergstrom, E., Jungvid, H., Vonderdecken, A., 1992. Effect of dietary keto acids on intermediary metabolism of nutrients in Atlantic salmon (Salmo salar) during 17-(-estradiol-induced vitellogenin synthesis. Acta Agric. Scand. A 42, 246-253.

Partanen, K.H., Mroz, Z., 1999. Organic acids for performance enhancement in pig diets. Nutr. Res. Rev. 12, 117-145.

Pierzynowski, S.G., Sjodin, A., 1998. Perspectives of glutamine and its derivatives as feed additives for farm animals. J. Anim. Feed Sci. 7, $79-91$.

Prandini, A., Morlacchini, M., Sigolo, S., Fiorentini, L., 2012. Anticatabolic activity of alpha-ketoglutaric acid in growing rats. Ital. J. Anim. Sci. 11, 279-284.

Rauch, F., 2007. Bone accrual in children: adding substance to surfaces. Pediatrics 119 (Suppl. 2), S137-140.

Ravindran, V., Kornegay, E.T., 1993. Acidification of weaner pig diets: a review. J. Sci. Food Agric. 62, 313-322.

Riedel, E., Nündel, M., Hampl, H., 1996. Alpha-ketoglutarate application in hemodialysis patients improves amino acid metabolism. Nephron 74, $261-265$.

Sakata, T., Adachi, M., Hashida, M., Sato, N., Kojima, T., 1995. Effect of n-butyric acid on epithelial cell proliferation of pig colonic mucosa in short-term culture. Deutsche Tierärztliche Wochenschrift 102, 163-164.

Sauer, W., Cervantes, M., Yanez, J., Araiza, B., Murdoch, G., Morales, A., Zijlstra, R.T., 2009. Effect of dietary inclusion of benzoic acid on mineral balance in growing pigs. Livest. Sci. 122, 162-168.

Shapiro, R., Heaney, R.P., 2003. Co-dependence of calcium and phosphorus for growth and bone development under conditions of varying deficiency Bone 32, 532-540.

Stoll, B., McNelly, S., Buscher, H.P., Haussinger, D., 1991. Functional hepatocyte heterogeneity in glutamate, aspartate and alpha-ketoglutarate uptake: a histoautoradiographical study. Hepatology 13, 247-253.

Tatara, M.R., Majcher, P., Krupski, W., Pierzynowski, S.G., Studzinski, T., 2004a. Influence of alpha-ketoglutarate on cortical bone density, geometrical properties and mechanical endurance of the humerus in turkeys. Bull. Vet. Inst. Pulawy 48, 461-465.

Tatara, M.R., Pierzynowski, S.G., Majcher, P., Krupski, W., Brodzki, A., Studziński, T., 2004b. Effect of alpha-ketoglutarate (AKG) on mineralisation, morphology and mechanical endurance of femur and tibia in turkey. Bull. Vet. Inst. Pulawy 48, 305-309. 
Tatara, M.R., Brodzki, A., Krupski, W., Sliwa, E., Silmanowicz, P., Majcher, P., Pierzynowski, S.G., Studzinski, T., 2005. Effects of alpha-ketoglutarate on bone homeostasis and plasma amino acids in turkeys. Poult. Sci. 84, 1604-1609.

Tatara, M.R., Tygesen, M.P., Sawa-Wojtanowicz, B., Krupski, W., Majcher, P., Harrison, A.P., 2007. Bone development: the effect of short-term alpha-ketoglutarate administration on long-term mechanical properties of ribs in ram lambs. Small Rumin. Res. 67, $179-183$.

Tatara, M.R., Krupski, W., Tymczyna, B., Studziński, T., 2012. Effects of combined maternal administration with alpha-ketoglutarate (AKG) and $\beta$-hydroxy- $\beta$-methylbutyrate (HMB) on prenatal programming of skeletal properties in the offspring. Nutr. Metab. 9, 1-12.

Wang, Y., Cho, J.H., Chen, Y.J., Yoo, J.S., Huang, Y., Kim, H.J., Kim, I.H., 2009. The effect of probiotic BioPlus 2 B ${ }^{\circledR}$; on growth performance, dry matter and nitrogen digestibility and slurry noxious gas emission in growing pigs. Livest. Sci. 120, 35-42.

Wang, L.S., Xu, Q.Y., Wang, C.A., Li, J.N., Chen, D., Zhao, Z.G., Luo, L., Du, X., 2015. Effects of dietary $\alpha$-ketoglutarate supplementation on the growth performance: glutamine synthesis and amino acid concentrations of juvenile hybrid sturgeon Acipenser schrenckii $q \times$ A. baerii $\sigma^{7}$ fed high levels of soy protein concentrate. Anim. Feed Sci. Technol. 211, 199-207.

Wu, G.Y., Thompson, J.R., 1990. The effect of glutamine on protein-turnover in chick skeletal-muscle in vitro. Biochem. J. 265 , 593-598.

Yao, K., Yin, Y.L., Li, X.L., Xi, P.B., Wang, J.J., Lei, J., Hou, Y.Q., Wu, G.Y., 2012. Alpha-ketoglutarate inhibits glutamine degradation and enhances protein synthesis in intestinal porcine epithelial cells. Amino Acids 42, 2491-2500.

Zhou, X., Thompson, J.R., 1997. Regulation of protein turnover by glutamine in heat-shocked skeletal myotubes. Biochim. Biophys. Acta 1357, $234-242$. 